\title{
Client Knowledge Opportunities for a Small Software Firm*
}

\author{
Mirella Migliaccio $^{* *}$, Francesca Rivetti $^{* * *}$
}

\begin{abstract}
In global markets, firms should be connected to a plurality of external actors to acquire knowledge for sustainable competitive advantage. Over the last decade, knowledge management scholars have highlighted the opportunity to acquire a wide spectrum of knowledge from clients, not limited to their characteristics and preferences. This opportunity is particularly evident, considering small software firms operating on commission, due to their interaction with clients; at the same time, it represents a challenge for small companies, because the knowledge acquired from clients is usually context-specific and can become an opportunity.
\end{abstract}

Keywords: Client Relationships; Customer Knowledge Management; Knowledge Acquisition; Knowledge Exploitation; Small Software Firms; Project Management

\section{Relational Approach and Customer Knowledge Management}

In the era of globalisation, no firm can operate in isolation (Brondoni 2009; Håkansson, Snehota 1989), but should be connected to a plurality of external actors with whom it can develop trustworthy relationships over time. This consideration has led scholars to emphasize the importance of relational economies and resource sharing in order to create a sustainable competitive advantage (Nooteboom 1999). Many forms of collaboration with different actors can favor the exchange and sharing of resources and knowledge/competences (Hakansson et al. 2009). This opportunity is evident when a firm overcomes the single dyadic relation and becomes a part of a wide network (Brondoni 2002; Granovetter 1973, 1985), where many actors (suppliers, clients, government agencies, research centers, logistics parties, etc.) participate in. Networks can take different configurations, depending on implicit and explicit rules characterizing the industries (Brondoni 2008) and the environmental contexts (Salvioni 2008).

The importance of relationships with external actors is particularly critical in the case of small firms because of their resource constraints, as many scholars highlight

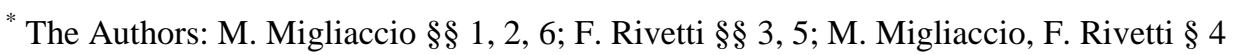

** Associate Professor of Management, University of Sannio (migliaccio@ unisannio.it)

*** Research Fellow in Management, University of Sannio (francesca.rivetti@unisannio.it)
}

Edited by: ISTEI - University of Milan-Bicocca

ISSN: $1593-0319$

Migliaccio Mirella, Rivetti Francesca (2013) Client Knowledge Opportunities. The Case for a Small Software Firm, Symphonya. Emerging Issues in Management (symphonya.unimib.it), n. 1, pp. 66 78 .

http://dx.doi.org/10.4468/2013.1.05migliaccio.rivetti 
(Desouza Awazu 2006; Sparrow 2001). Naturally, this constitutes a challenge for small enterprises, since it is necessary to develop absorptive (Cohen, Levinthal 1990) and relational capabilities (Dyer, Singh 1998; Lorenzoni, Lipparini 1999) in order to benefit from the opportunities of globalization.

The relational approach has deepened especially with reference to business-tobusiness contexts (Fill, Fill 2004; Tunisini 1995; Tunisini, Zanfei 1998), where particular emphasis is put on the client-supplier relationship. Such relationship is very important in the case of firms operating on commission, which normally cooperate with clients in order to carry out specific projects. The emergence of a globalized economy and the consequent change of rules of the competitive game have led these enterprises to switch from an isolated view of "value shop" business model to a network perspective, where each relationship is included in a web of links (Stabell, Fjeldstad 1998).

In the last decade, a relatively new stream of research has emerged, focused on the management of knowledge related to the customer (Garcia-Murillo, Annabi 2002; Gibbert et al. 2002; Salomann et al. 2005). Scholars have highlighted the opportunity to acquire from clients a wide spectrum of knowledge, not limited to their characteristics and preferences: not only what clients want, but above all what clients know.

Based on customer knowledge management and project management research, this article focuses on the management of client-related knowledge with particular emphasis on its acquisition and on the opportunities for its exploitation, considering small software firms operating on commission. The paper attempts to address the following questions: How do the project-based software firms manage clientrelated knowledge, and how do they exploit this knowledge? To address these questions, a longitudinal case study is conducted. This methodology allows us to analyze the phenomenon under observation and to define propositions to be tested in further research.

The remainder of the paper is structured as follows. The second section aims at building the concept of client-related knowledge, based on customer knowledge management literature. The third section explores the issue with reference to small software service firms. After the methods are briefly outlined, the fifth section presents the case study. In the conclusions, the empirical results are discussed and propositions for further research are presented.

\section{The Relevance of Client Knowledge}

Knowledge is the most significant resource for building and sustaining competitive advantage (Grant 1996; Ichijo, Nonaka 2007; Zack 1999). Tacit and explicit knowledge can not only be generated internally, but also acquired from external sources (Grant, Baden-Fuller 2004; Huber 1991; Zhara, George 2002). Explicit knowledge can be readily captured in tangible forms, and therefore can be easily communicated, while tacit knowledge is difficult to articulate (Nonaka, Takeuchi 1995) and can be transmitted only through social interaction (HernandezSerrano et al. 2002; Leonard, Sensiper 1998). Grant and Baden-Fuller (2004) point 
out that knowledge acquisition, unlike access, enhances the knowledge base of an organization.

External knowledge can be acquired from various sources, the importance of which depends on the characteristics of the recipient's knowledge base (Asheim, Gertler 2005). Scholars distinguish between vertical (e.g., suppliers, customers) and horizontal links (competitors). Knowledge links with customers have been considered especially in innovation and marketing literature.

Innovation studies are mainly focused on the acquisition of knowledge from users, especially during NPD (Bogers et al. 2010; von Hippel 1988). Their importance is emphasized especially with reference to the opportunity to capture needs and preferences which are (or will be) common in the market (von Hippel 1986) (in the case of the lead users), and to benefit from their innovations (von Hippel 2001).

Nowadays the marketing research is particularly focused on the knowledge 'about' customers (Rowley 2006). Within this field, Customer Relationship Management (CRM) refers to the creation, enhancement, and preservation of relationships with customers (Addis et al. 2002; Galbreath, Rogers 1999). On this regard marketing scholars highlight the importance of market sensing and customer-linking capabilities (Day 1994), instrumental to learn about customer, competitors and channel operators, and to create relationships with customers. These capabilities characterize market-driven organizations (Brondoni 2012; Lambin, Brondoni 2001).

Especially in the last decade the knowledge management scholars have started to focus on the development of learning relationships with clients, developing the concept of client knowledge (Gibbert et al. 2002; Rowley 2006; Salomann et al. 2005). Customer Knowledge Management (CKM) aims at "gaining knowledge directly from the customer, as well as sharing and expanding this knowledge" (Gibbert et al. 2002).

Relying on the development of databases, CRM aims to learn about the customer's needs and motivations (Rowley 2006), whereas CKM aims to manage knowledge relating to customers (individuals and/or other organizations) (GarciaMurillo, Annabi 2002; Gibbert et al. 2002), focusing on social interaction.

According to Rowley (2006), customer-related knowledge includes knowledge about customers, instrumental "to understanding customers' motivation and to address them in a personalised way"; knowledge from customers, concerning "products, suppliers and markets"; knowledge for customers, which is essential "to satisfy customers' knowledge needs"; knowledge retained by customers, "which may be used in a co-learning or innovation process".

$\square$ "The way IKEA, the living environment furniture retailer, presents itself to customers is all about co-production, about how benefits and activities have been reallocated between producer and customer. The CKM process in IKEA transforms the customer into a co-value creator, endowing him/her with new competencies and benefaction opportunities. It liberates the customer from the platform of only past, accumulated knowledge by stimulating him with a pattern of openended value-creating ideas, thereby effecting co-production and mutual 
new value evidenced in new IKEA furniture products and services" (Gibbert et al. 2002).

The opportunity to acquire and manage different components of customer-related knowledge depends, among others, on the frequency of interaction, the duration and openness of the tie, as well as the cognitive distance among actors (Gilsing, Nooteboom 2006).

$\square$ The process of socialisation that he (Nonaka) describes in his 1998 article focuses on the process that would normally take place within the context of a company. As he explains: "[S]ocialisation involves the sharing of tacit knowledge between individuals ... [We] use the term socialisation to emphasize that tacit knowledge is exchanged through joint activities-such as being together, spending time, living in the same environment-rather than written or verbal instructions. Interactions with customers could not reach this level of intimacy but the idea of trying to socialize with the customer to tap into their knowledge can contribute to the pool of knowledge of the company. This can be more easily achieved for recurring customers with whom the salesperson can develop a closer relationship" (Garcia-Murillo, Annabi 2002).

In a B2B market this implies that small firms should be able to develop a web of relations with clients, considered as partner with whom they have frequent interactions (Brondoni 2002). These aspects, in turn, are related to the output (product or service), to its characteristics, to the market (business-to-business or business-to-consumer), and finally to the standardization/customization model (pure standardization, segmented standardization, customized standardization, tailored customization, pure customization) (Lampel, Mintzberg 1996) undertaken by the company. In general, it seems reasonable to suppose that a project-based firm operating in the service business in a business-to-business context can interact with its clients on many occasions, tends to develop with them long-term relationships characterized by high openness, and usually presents a low cognitive distance with respect to its clients.

Always more frequently the scholars consider the client as a partner with whom they develop a trustworthy relationship (Sobel 2009). Of course, to benefit from interaction with the client in terms of learning, relation-specific investments may be necessary (Nooteboom 1999). Moreover, motivational and cognitive barriers to the knowledge sharing need to be removed (Gibbert et al. 2002). Nevertheless the development of absorptive (Cohen, Levinthal 1990; Zhara, George 2002) and relational capabilities (Dyer, Singh 1998; Lorenzoni, Lipparini 1999) is necessary.

This paper focuses on small software firms operating on commission, whose clients are constituted by other enterprises. It refers to the broad spectrum of knowledge related to the client, which is termed 'client-related knowledge' herein, and can present a high degree of tacitness. The management of client-related knowledge is explored, with particular emphasis on its acquisition and exploitation. 


\section{Client-Related Knowledge Management in Small Software Firms}

The importance of clients as a source of knowledge for small software service firms has been widely emphasized by scholars (Torrisi 1998; Trippl et al. 2009; Weterings, Boschma 2009). Although the contribution of clients in terms of knowledge is considered particularly critical to define and reach project goals (Migliaccio 1995; Torrisi 1998), as Segelod and Jordan (2004) have pointed out, they constitute the most important source of knowledge during the whole project for software development. The requirements could emerge during process development, when software firms must be open to clients' influence and feedback, which may result in requirement changes, and consequently in software modifications (Segelod, Jordan 2004). Sandhawalia and Dalcher (2010) claim the amount of required knowledge related to clients "depends upon the novelty and uniqueness of the required outcome". Therefore, in the case of commissioned software, it is usually very high.

Knowledge acquired from clients is characterized by a high degree of tacitness and is usually context-specific (Torrisi 1998). Therefore, its reuse constitutes a challenge. Nambisan (2001) notes firms operating in the service business are often involved in "mundane" business applications and interact with unsophisticated users. However, service companies often develop customized or ex-novo software for different companies. Moreover, usually they develop long-term relations with their clients (Gopal et al. 2003) that can go beyond specific projects. This close relationship may involve access to a wide range of knowledge. As Cusumano (2004) highlights, the relationships with main clients may lead service software firms to exploit opportunities represented by economies of scope and the "lock in" effect. Thus, clients become partners, since trusted relationships are developed and a wide range of knowledge is acquired from them and shared with them. A particularly critical decision that can deeply affect knowledge acquisition concerns the software project management methodology, which determines the modalities of interaction with the client during the project. The waterfall model (Royce 1970) limits the interaction with the client to the beginning and the end of the project, while the spiral model (Boehm 1988) and rapid prototyping (Connel, Shafer 1989) rely on interactions especially at the end of each stage. Finally, agile models (Anderson 2004) emphasize continuous interactions.

As highlighted in the opening to this paper, the spectrum of knowledge that the firm can gain from clients can be very broad (Rowley 2006), going beyond knowledge instrumental to the achievement of the specific project. Of course, the different project management methodologies influence the management of a differently wide spectrum of client-related knowledge, which can then be exploited in many ways beyond the specific project. This issue has been little explored by scholars, but constitutes a promising topic.

\section{Methodology}

Based on the literature review and our research questions, we decided to adopt a qualitative approach, which is particularly useful in cases where "the exploration of 
detailed in-depth data" is required (Johnson, Harris 2002). The research design is a longitudinal single case study, which seems suitable to explore the dimensions of the phenomenon investigated. Case study research, in fact, offers a high degree of accuracy and low generalization of findings (Woodside 2010).

The case was selected by considering its relevance to the phenomenon under investigation and its accessibility. We choose a firm that normally aims at managing a wide spectrum of knowledge related to the client and develop with clients long-term, trusty relationships. At the same time, this company provides easy access to data and information.

The analysis covers a period of three years (2011-2013), during which multiple research methods (e.g., interviews, both structured and semi-structured, participant observation, analysis of internal documents) were employed. Data were organized on the basis of the key issues identified with reference to the phenomenon. In this way, it was easier to emphasize the role of the management of client-related knowledge and to understand better how it works.

\section{The Case of Alpha}

Alpha ${ }^{1}$ srl is an Italian group based in Naples that operates in the software industry. It was established in 1997 by a group of managers of software enterprises. Supported by about 40 professionals and experts, it has 25 employees. The group offers a wide range of technology solutions, flexible and modular, in line with the more advanced technologies. It pursues the mission of early followers (Grant 1998; Teece 1987), enhances horizontal and vertical relationships with many external actors (e.g., universities and research centers, competitors, clients), and adopts a network approach. This group supports the entire life cycle of its clients' information systems, developing software and operating as system integrators. Moreover, through Beta srl, it explores new technological solutions and carries out projects in the areas of e-learning, GIS, video surveillance, and security. Another member of the group is Gamma srl, which focuses on CRM, workflow management, document management, and business intelligence solutions. Its main clients are constituted by the Public Administration.

Among the different models of software development, the group mainly uses the spiral model and rapid prototyping. These models are particularly suitable to reach the objectives of the specific project. They fit with client's requirements, keeping the costs of the project down, and minimizing the development time (Schilling 2004). Moreover, they favor the development of learning relationships with clients, which constitute a prerequisite to acquire a broad spectrum of knowledge from them, going beyond the specific projects carried out for them and defining opportunities for cooperation, including joint participation in conferences, seminars, and in other projects.

Focusing on the projects, it should be noted that the successful implementation of the models depends on the definition and implementation of multiple and specific moments of interaction between Alpha's human resources and the client company. Operationally, Alpha uses specific mechanisms facilitating the acquisition of tacit knowledge and activates mechanisms of the client's motivation. 
The propensity to acquire knowledge from clients is also reflected in some organizational choices. For example, there is not an organizational unit performing commercial functions. This corresponds to a pondered organizational choice, following the necessity to promote interaction with clients of all organizational members at all levels, and ensuring that everybody in the company listens to and interacts with the client. This favors not only the acquisition, but also the dissemination of knowledge into the whole organization. In addition, knowledge roles are assigned to some employees in order to facilitate not only the sharing of knowledge (knowledge gatekeeper), but also its codification and translation of specific needs into requirements for knowledge (knowledge analyst) and dissemination (knowledge facilitator). The group also organizes training programs aimed at improving its relationships with clients. Below, we analyze two cases concerning two projects (Zeta and Theta) carried out by Alpha, which constitute opportunities to acquire and manage client-related knowledge, then reused in other projects.

\subsection{The Zeta Project}

A client, Delta srl, based in Naples (near Alpha headquarters) and operating in the energy industry, commissions Alpha srl to check the production of photovoltaic panels. During the whole project (here named the 'Zeta Project') implemented by using the spiral model, Alpha interacts frequently with Delta by using instruments enabling direct and mediated interaction. Moreover, the project team promotes the joint drafting of project documents, constituting a stimulus for knowledge articulation as well as codification (Prencipe, Tell 2001; Zollo, Winter 2002). This allows Alpha to reduce the risk associated with the project, acquiring fundamental knowledge for its successful implementation. At the same time, Alpha enhances its knowledge base through knowledge concerning the market, know-how in the field of energy, modalities of capturing and aggregation, problems concerning the management of a large amount of data and variability of the data itself, and layout and modalities of the presentation of the data.

After a while, 'Epsilon', a multi-utility company which maintains supplies of electricity and gas, asks Alpha to create a gaming monitor concerning the consumption of its customers. At this point, much of the knowledge gained from the previous client reveals an indispensable resource to carry out this project. As the CEO of Alpha highlights, "we re-used knowledge acquired from Zeta, partially crystallized in documents, online archives, and in the source code. We changed some writings on the screens and what was instrumental to the production has become instrumental to the consumption".

\subsection{The Theta Project}

A client commissions Alpha to undertake a project (the 'Theta project') instrumental to carrying out a system to monitor the production of a photovoltaic plant. Alpha develops a software to present data a 'produced energy' and 'instant power', and to carry out a functionality of aggregation and criteria for access at all levels. Also in this case Alpha implements the project by using the spiral model, 
thus stimulating continuous interaction with the client; moreover, it favors knowledge articulation and codification by promoting joint drafting of documents.

As it happened in the Zeta Project, during Theta Project, Alpha acquires from the client knowledge about the market, know-how in the field of energy, management of data, as well as modalities of presentation of data.

Subsequently, another company, which resells electricity and gas, commissions Alpha to monitor the consumption of energy. The system developed by Alpha serves to detect the information from energy meters; it is easy to install, not connected to the electricity grid, with a range of a few years, and is able to communicate data in adverse environments (e.g. from the basement of a building up to an apartment on the $4^{\text {th }}$ floor of the building). In doing so, Alpha is able to recover all of the presentation software previously realized by simply reversing the concept of 'Energy produced' with 'Energy consumed'. Again, knowledge previously gained from a client is reused to carry out another project for a different client.

\section{Client Relationships and Knowledge Opportunities}

Small software enterprises operating in the service business need to overcome the 'value shop' logic to adopt a network approach (Stabell, Fjelstad 1998). They should access knowledge possessed by actors not only upstream, but also downstream. Focusing on vertical relationships, and more specifically on relationships with clients, the paper highlights the role of client-related knowledge for software firms operating on commission, which goes beyond those strictly instrumental to the specific project and therefore is critical to carrying out other projects. Moreover, it emphasizes the opportunity to define mechanisms of interactions, motivating clients to share knowledge, and mechanisms to favor the management of the acquired knowledge, going beyond what is prescribed by the models of project management adopted by the firm.

With regard to the first research question (How do project-based software firms manage client knowledge?), the following aspects can be emphasized. First, it is important to note that the development of learning relationships with clients can allow a firm to gain a broad spectrum of knowledge (Rowley 2006), concerning, among other things, opportunities for innovation (Nieto, Santamaria 2010), competitors, suppliers, and complementary as well as substitute products. This knowledge usually presents a high degree of tacitness and therefore is acquired mainly individually, through interaction. The company can favor knowledge articulation (Prencipe, Tell 2001; Zollo, Winter 2002), which in turn can amplify the acquisition, by promoting interaction at all levels and beyond what was prescribed by the specific model of software development adopted. To reduce the risk of losing the acquired knowledge, favoring retention, it seems necessary to activate specific mechanisms of codification and dissemination, through which the client-related knowledge becomes organizational. To this end, meetings among organizational members and the redaction of documents with the client can constitute two useful instruments. 
Of course, software firms operating on commission can interact with clients also on other occasions to gain their knowledge (e.g. partnerships over research projects, conferences, workshops, and other events). The multiplicity of opportunities for collaboration can also allow firms to overcome the limits imposed to knowledge acquisition by the temporariness of specific projects. Accordingly we define the first proposition for further research:

Proposition 1: Software firms operating on commission should seize the opportunities represented by client-related knowledge, managing it by activating individual and organizational learning mechanisms.

With reference to the second research question (How do firms exploit this knowledge?), it should be noted that, especially for service firms, acquired knowledge might lead to economies of scope. In fact, it can be reused in other projects carried out on behalf of same client or other clients, but also beyond projects. These aspects have been little explored in the literature. These firms overcome the conventional access-based approach, to enhance their knowledge base. They acquire a wide spectrum of client related knowledge and identify many opportunities for exploitation. This allows us to define a second proposition.

Proposition 2: Software firms operating on commission, enacting mechanisms of organizational learning, create the preconditions for the reuse of client-related knowledge in other projects.

The case study highlighted the benefits and opportunities of knowledge resulting from the interaction with the clients. However, it should be noted that client-related knowledge might be 'incorrect'. This means that, for example, you might catch a distorted view of the client's problem or that the knowledge that the client possesses, concerning suppliers, substitute and complementary products, and so on, does not correspond to the reality. The mechanisms of organizational learning could cope with these aspects. Future research could address these issues. Therefore, it is possible to define a third proposition:

Proposition 3: software firms operating on commission, enacting mechanisms of organizational learning, can create the preconditions to understand risks and to identify threats connected to some projects for exploitation of client problem knowledge.

\section{Bibliography}

Addis Michela, Bona Fabrizio, Costabile Michele, Padula Giovanna (2002) The Customer Relationship Management. Omnitel Vodafone, 6th Research Conference on Relationship Marketing \& CRM, Atlanta, GA.

Anderson David J. (2004) Agile Management for Software Engineering, Prentice-Hall, Upper Saddle River, NJ.

Asheim Bjorn T., Gertler Meric S. (2005) The Geography of Innovation: Regional Innovation Systems, in Jan Fagerberg, David C. Mowery, Richard R. Nelson (Eds), The Oxford Handbook of Innovation, Oxford University Press, Oxford, pp. 291-317. http://dx.doi.org/10.1093/oxfordhb/9780199286805.003.0011

Boehm Barry W. (1988) A Spiral Model of Software Development and Enhancement, IEEE Computer, vol. 21, n. 5, pp. 61-72.

http://dx.doi.org/10.1109/2.59 
Bogers Marcel, Afuah Allan, Bastian Bettina (2010) Users as Innovators: A Review, Critique, and Future Research Directions, Journal of Management, vol. 36, n. 4, pp. 857-875.

http://dx.doi.org/10.1177/0149206309353944

Brondoni Silvio M. (2002) Ouverture de 'Corporate Culture and Market Complexity', Symphonya. Emerging Issues in Management (symphonya.unimib.it) n. 2, pp. 1-6. http://dx.doi.org/10.4468/2002.2.01ouverture

Brondoni Silvio M. (2009) Market-Driven Management, Competitive Customer Value and Global Networks, Symphonya. Emerging Issues in Management (symphonya.unimib.it), n. 1, pp. 8-25. http://dx.doi.org/10.4468/2009.1.02brondoni

Brondoni Silvio M. (2012) Market-Driven Management and Corporate Growth, Giappichelli, Turin. http://hdl.handle.net/10281/38958

Cohen Wesley M., Levinthal Daniel A. (1990) Absorptive Capacity: A New Perspective on Learning and Innovation. Administrative Science Quarterly, vol. 35, n. 1, pp. 128-152. http://dx.doi.org/10.2307/2393553

Connell John L., Shafer Linda B. (1989) Structured Rapid Prototyping: An Evolutionary Approach to Software Development, Yourdon Press, Englewood Cliffs, NJ.

Cusumano Michael A. (2004) The Business of Software: What Every Manager, Programmer and Entrepreneur Must Know to Thrive and Survive in Good Times and Bad. Free Press, New York.

Day George S. (1994) The Capabilities of Market-Driven Organizations, Journal of Marketing, vol. 58, n. 4., pp. 37-52. http://dx.doi.org/10.2307/1251915

Day George S. (2001) Market-Driven Winners, Symphonya. Emerging Issues in Management (symphonya.unimib.it), n. 2, pp. 12-22.

http://dx.doi.org/10.4468/2001.2.02day

Dyer Jeffrey H., Singh Harbir (1998) The Relational View: Cooperative Strategy and Sources of Interorganizational Competitive Advantage, Academy of Management Review, vol. 23, n. 4, pp. 660-679. http://dx.doi.org/10.5465/AMR.1998.1255632

Desouza Kevin C., Awazu Yukika (2006) Knowledge Management at SMEs: Five Peculiarities, Journal of Knowledge Management, vol. 10, n. 1, pp. 32-43. http://dx.doi.org/10.1108/13673270610650085

Fill Chris, Fill Karen E. (2004) Business-to-Business Marketing: Relationships, Systems and Communications, Pearson, Harlow.

Galbreath Jeremy, Rogers Tom (1999) Customer Relationship Leadership: A Leadership and Motivation Model for the Twenty-First Century Business, The TQM Magazine, vol. 11, n. 3, pp. 161-171. http://dx.doi.org/10.1108/09544789910262734

Garcia-Murillo Martha, Annabi Hala (2002) Customer Knowledge Management, The Journal of the Operational Research Society, vol. 53, n. 8, pp. 875-884. http://dx.doi.org/10.1057/palgrave.jors.2601365

Gibbert Michael, Leibold Marius, Probst Gilbert (2002) Five Styles of Customer Knowledge Management, and How Smart Companies Use Them To Create Value, European Management Journal, vol. 20, n. 5, pp. 459-469. http://dx.doi.org/10.1016/S0263-2373(02)00101-9

Gilsing Victor, Nooteboom Bart (2006) Exploration and Exploitation in Innovation Systems: The Case of Pharmaceutical Biotechnology, Research Policy, vol. 35, n. 1, pp.1-23. http://dx.doi.org/10.1016/j.respol.2005.06.007

Gopal Anandasivam, Sivaramakrishnan Konduru, Krishnan, M.S., Mukhopadhyay Tridas (2003). Contracts in Offshore Software Development: An Empirical Analysis, Management Science, vol. 49, n. 12, pp. 1671-1683. http://dx.doi.org/10.1287/mnsc.49.12.1671.25120 
Granovetter Mark S. (1973) The Strength of Weak Ties, American Journal of Sociology, vol. 78, n. 6, pp. 1360-1380.

http://dx.doi.org/10.1086/225469

Granovetter Mark S. (1985) Economic Action and Social Structure: The Problem of Embeddedness, American Journal of Sociology, vol. 91, n. 3, pp. 481-510. http://dx.doi.org/10.1086/228311

Grant Robert M. (1996) Toward a Knowledge Based Theory of the Firm, Strategic Management Journal, vol. 17, Winter Special Issue, pp. 109-123.

Grant Robert M. (1998) Contemporary Strategy Analysis, Blackwell Publishers, Malden, MA.

Grant Robert M., Baden-Fuller Charles (2004) A Knowledge Accessing Theory of Strategic Alliances, Journal of Management Studies, vol. 41, n. 1, pp. 61-84. http://dx.doi.org/10.1111/j.1467-6486.2004.00421.x

Håkansson Hakan, Ford David I., Gadde Lars E., Snehota, Ivan, Waluszewski Alexandra (2009) Business in Networks, Wiley, Chichester, Sussex.

Håkansson, H., Snehota, I. (1989) No Business Is an Island: The Network Concept of Business Strategies, Scandinavian Journal of Management, vol. 5, n. 3, pp. 187-200. http://dx.doi.org/10.1016/0956-5221(89)90026-2

Hernandez-Serrano Julián, Stefanou Spiro E., Hood Lamartine F., Zoumas Barry L. (2002) Using Experts' Experiences through Stories in Teaching New Product Development, Journal of Product Innovation Management, vol. 19, n. 1, pp. 54-68. http://dx.doi.org/10.1016/S0737-6782(01)00118-7

Huber George P. (1991) Organizational Learning: The Contributing Processes and the Literatures, Organization Science, vol. 2, n. 1, pp. 88-115.

http://dx.doi.org/10.1287/orsc.2.1.88

Ichijo Kazuo, Nonaka Ikujiro (Eds.) (2007) Knowledge Creation and Management. New Challenges for Managers, Oxford University Press, NY.

Johnson Phil, Harris Don (2002) Qualitative and Quantitative Issues in Research Design, in David Partington (ed.), Essential Skills for Management Research, Sage, London.

Lambin Jean-Jaques, Brondoni Silvio M. (2001) Ouverture de 'Market-Driven Management', Symphonya. Emerging Issues in Management (symphonya.unimib.it), $\mathrm{n} . \quad 2$. http://dx.doi.org/10.4468/2001.2.01ouverture

Lampel Joseph, Mintzberg Henry (1996) Customizing Customization, Sloan Management Review, vol. 38, n. 1, pp. 21-30.

http://sloanreview.mit.edu/article/customizing-customization/

Leonard Dorothy, Sensiper Sylvia (1998) The Role of Tacit Knowledge in Group Innovation, California Management Review, vol. 40, n. 3, pp. 112-132.

http://www.jstor.org/stable/41165946

Lorenzoni Gianni, Lipparini Andrea (1999) The Leveraging of Interfirm Relationships as a Distinctive Organizational Capability: A Longitudinal Study, Strategic Management Journal, vol. 20, n. 4, pp. 317-337. http://dx.doi.org/10.1002/(SICI)1097-0266(199904)20:4<317::AID-SMJ28>3.0.CO;2-3

Nambisan Satish (2001) Why Service Businesses Are Not Product Businesses, MIT Sloan Management Review, vol. 42, n. 4, pp. 72-80.

http://sloanreview.mit.edu/article/why-service-businesses-are-not-product-businesses/

Nieto Maria J., Santamaria Lluís (2010) Technological Collaboration: Bridging the Innovation Gap between Small and Large Firms, Journal of Small Business Management, vol. 48, n. 1, pp. 44-69. doi:10.1111/j.1540-627X.2009.00286.x, http://dx.doi.org/10.1111/j.1540-627X.2009.00286.x

Nonaka Ikujiro, Takeuchi Hirotaka (1995) The Knowledge-Creating Company, Oxford University Press. Oxford.

Nooteboom Bart (1999) Innovation and Inter-Firm Linkages: New Implications for Policy, Research Policy, 28 (8), 793-805. 
http://dx.doi.org/10.1016/S0048-7333(99)00022-0

Nooteboom Bart (1999) Inter-firm Alliances. Analysis and Design, Routledge, London.

Prencipe Andrea, Tell Fredrik (2001) Inter-Project Learning: Processes and Outcomes of Knowledge Codification in Project-Based Firms, Research Policy, vol. 30, n. 9, pp. 1373-1394. http://dx.doi.org/10.1016/S0048-7333(01)00157-3,

Rowley Jennifer (2006) Customer Knowledge Management, Academy of Management Best Papers Proceedings.

http://www.aom-iaom.org/pdfs/jms/JSM-18-06_rowley.pdf

Royce Winston W. (1970) Managing the Development of Large Software Systems: Concepts and Techniques. Procedures WESCON, Western Electric Show and Convention, Los Angeles. Proceedings of the 11th International Conference of Software Engineering, Pittsburgh, PA.

Salomann Harald, Dous Malte, Kolbe Lutz, Brenner Walter (2005) Rejuvenating Customer Management: How to Make Knowledge For, From and About Customers Work, European Management Journal, vol. 23, n. 4, pp. 392-403.

http://dx.doi.org/10.1016/j.emj.2005.06.009

Salvioni Daniela M. (2008) Market-Driven Management and Corporate Governance, Symphonya. Emerging Issues in Management (symphonya.unimib.it), $\quad \mathrm{n} . \quad 2, \quad$ pp. 13.27. http://dx.doi.org/10.4468/2008.2.02salvioni

Sandhawalia Birinder S., Dalcher Darren (2010) Knowledge Flows in Software Projects: An Empirical Investigation, Knowledge and Process Management, vol. 17, n. 4, pp. 205-220. http://dx.doi.org/10.1002/kpm.357

Shilling Melissa (2004) Strategic Management of Technological Innovation, McGraw-Hill, New York.

Segelod Esbjörn, Jordan Gary (2004) The Use and Importance of External Sources of Knowledge in the Software Development Process, $R \& D$ Management, vol. 34, n. 3, pp. 239-252.

http://dx.doi.org/10.1002/kpm.357

Sobel Andrew (2009) All for One. 10 Strategies for Building Trusted Client Partnerships, Wiley, Hoboken, NJ.

Sparrow John (2001) Knowledge Management in Small Firms, Knowledge and Process Management, vol. 8, n. 1, pp. 3-16.

http://dx.doi.org/10.1002/kpm.92

Stabell Charles B., Fjeldstad Øystein D. (1998) Configuring Value for Competitive Advantage: On Chains, Shops, and Networks, Strategic Management Journal, vol. 19, n. 5, pp. 413-437. http://dx.doi.org/10.1002/(SICI)1097-0266(199805)19:5<413::AID-SMJ946>3.0.CO;2-C

Teece David J. (1987) The Competitive Challenge: Strategies for Industrial Innovation and Renewal, Ballinger, Cambridge.

Torrisi Salvatore (1998) Industrial Organization and Innovation: An International Study of the Software Industry, Edward Elgar Publishing, Cheltenham, UK.

Trippl Michaela, Tödtling Franz, Lengauer Lukas (2009) Knowledge Sourcing Beyond Buzz and Pipelines: Evidence from the Vienna Software Sector, Economic Geography, vol. 85, n. 4, pp. 443-462.

http://dx.doi.org/10.1111/j.1944-8287.2009.01047.x

Tunisini Annalisa (1995) The Evolution of Customer Relationships in Large High-Tech Companies: The Marketing Management Implications, European Journal of Marketing, vol. 29, n. 5, pp. 8889.

Tunisini Annalisa, Zanfei Antonello (1998) Exploiting and Creating Knowledge through CustomerSupplier Relationships: Lessons from a Case Study, $R \& D$ Management, vol. 28, n. 2, pp. 111-118. http://dx.doi.org/10.1111/1467-9310.00087

von Hippel Eric (1986) Lead Users: A Source of Novel Product Concepts, Management Science, vol. 32, n. 7, pp. 791-805.

http://dx.doi.org/10.1287/mnsc.32.7.791

von Hippel Eric (1988) The Sources of Innovation, Oxford University Press, Oxford. 
von Hippel Eric (2001) Innovation by User Communities: Learning from Open Source Software, Sloan Management Review, vol. 42, n. 4, pp. 82-86.

http://sloanreview.mit.edu/article/innovation-by-user-communities-learning-from-opensourcesoftware/

Weterings Anet, Boschma Ron (2009) Does Spatial Proximity to Customers Matter for Innovative Performance? Evidence from the Dutch Software Sector, Research Policy, vol. 38, n. 5, pp. 746755.

http://dx.doi.org/10.1016/j.respol.2008.12.011

Woodside Arch G. (2010) Bridging the Chasm between Survey and Case Study Research: Research Methods for Achieving Generalization, Accuracy, and Complexity, Industrial Marketing Management, vol. 39, n. 1, pp. 64-75.

http://dx.doi.org/10.1016/j.indmarman.2009.03.017

Zack Michael H. (1999) Developing a Knowledge Strategy, California Management Review, vol. 41, n. 3, pp. 125-145.

Zahra Shaker A., George Gerard (2002) Absorptive Capacity: A Review, Reconceptualization, and Extension, Academy of Management Review, vol. 27, n. 2, pp. 185-203. http://dx.doi.org/10.5465/AMR.2002.6587995

Zollo Maurizio, Winter Sydney G. (2002) Deliberate Learning and the Evolution of Dynamic Capabilities, Organization Science, vol. 13, n. 3, pp. 339-351.

http://dx.doi.org/10.1287/orsc.13.3.339.2780

\section{Notes}

${ }^{1}$ To preserve the anonymity of the companies mentioned in this case study, we use invented names. 